\title{
Implications of Public External Debt for Social Spending: A Case Study of Selected Asian Developing Countries
}

\author{
Sadia Shabbir* and Hafiz M. Yasin ${ }^{* *}$
}

\begin{abstract}
For developing countries with budgetary and balance-of-payments gaps to meet, maintaining large stakes of external debt is not free of cost. Highly indebted countries have to set aside a sizeable fraction of their scarce resources to service their debt, which naturally affects their development spending in general and allocations for the social sector in particular. This study examines the behavior of seven developing Asian countries and analyzes the impact of public external debt on social sector spending. The panel dataset includes Pakistan, India, Bangladesh, Sri Lanka, Nepal, the Philippines, and Indonesia, and spans the period 1980-2010. Our empirical analysis is based on three interrelated equations for different spending categories, which are estimated using the general method of moments. The study's results confirm the common wisdom that outstanding external debt and its servicing liability have an adverse impact on public spending, particularly on social sector spending. This suggests that developing countries need to mobilize their own resources and minimize their dependence on external borrowing as far as possible.
\end{abstract}

Keywords: Public debt outstanding, debt servicing, fiscal deficit, current account deficit, social sector development.

JEL classification: H69.

\section{Introduction}

Access to financial assistance is important to individuals, business organizations, and governments. The "three-gap model" explains why developing countries facing fiscal and balance-of-payments problems often resort to foreign aid. ${ }^{1}$ Different variants of this model are frequently used by donor agencies in country analyses to define the relative need for

\footnotetext{
* International Islamic University, Islamabad.

*** Associate Professor, International Islamic University, Islamabad.

${ }^{1}$ From the macro-identity $\mathrm{C}+\mathrm{I}+\mathrm{G}+(\mathrm{X}-\mathrm{M})=\mathrm{Y}=\mathrm{C}+\mathrm{S}+\mathrm{T}+\mathrm{F}$, one obtains the relationship (I $\mathrm{S})+(\mathrm{G}-\mathrm{T})=(\mathrm{M}-\mathrm{X})$. Here, $(\mathrm{I}-\mathrm{S})$ shows the resource gap between investment and saving in the private sector; $(\mathrm{G}-\mathrm{T})$ shows the budget gap of the public sector; and $(\mathrm{M}-\mathrm{X})$ is the trade or foreign exchange gap, which has to be financed through foreign borrowing or foreign capital inflows $(F)$.
} 
and ability of the government concerned to use foreign aid effectively (Islamov, 2001). However, continued reliance on foreign borrowing is not costless. ${ }^{2}$ Servicing accumulated foreign debt absorbs a significant fraction of the meager resources generated through exports and remittances. This, in turn, creates the need for further borrowing and widens the fiscal deficit. Data from developing countries reveal that cutting down on current (nondevelopment) expenditure is seldom feasible. The final outcome is straightforward: debt servicing adversely affects ongoing development projects and allocations for social sectors such as health and education.

External borrowing is considered important for developing countries because it increases their access to foreign resources in order to finance imports (equipment and material) meant for development projects. The practice of borrowing may be useful in the short run, but it has important long-run consequences: resources have to be generated first through exports and then used to pay back and service the outstanding debt.

All this depends on the careful and efficient use of the borrowed funds. It is not possible for the central bank to print the hard currency (foreign exchange) needed to repay external debt, and so external borrowing is often associated with vulnerability and debt crises (Rais \& Anwar, 2012). The case of domestic public borrowing is somewhat different. The government can easily raise fresh loans to repay mature bonds. The resources are then simply transferred from one hand (taxpayers) to the other (bond holders) in the case of domestic debt servicing.

Many developing countries' government liabilities have increased due to rising interest payments, price hikes of oil imports, and unfavorable conditions in the international markets for their primary exports. As a result, they are caught in a vicious circle of deficit and debt: the increasing budget and trade deficits lead to more borrowing while debt accumulation over time causes the fiscal deficit to widen further. Their current expenditure has also risen over time due to overspending, and this behavior is also motivated by the availability of foreign aid and easy borrowing (Shonchoy, 2010).

Post-1980s, most low-income developing countries have relied on external borrowing to finance development programs in infrastructure,

\footnotetext{
${ }^{2}$ Here, we do not discuss the social and political costs of indebtedness, which countries may have to bear in the form of loss of integrity and freedom in decision-making.
} 
construction, power generation, and the social sector. Development of these sectors is important to raise people's living standards. The impact of external debt on social sector spending is a controversial issue. Mahdavi (2004), for example, emphasizes spending cuts and higher revenues, and suggests distributing the total cuts appropriately among the various categories of public spending in order to reduce the fiscal deficit.

However, a reduction in current spending by the government is often difficult, given the adverse effect on welfare and employment, which can exacerbate public discontent and political instability. If, however, the funds released from cuts in current spending are applied carefully to enhance productivity, then this strategy may be effective for economic growth in the long run. This holds particularly for those developing countries where the public sector is the main provider of employment and the major source of investment in infrastructure and fixed capital formation.

High stakes of debt lead to greater servicing liability. Increasing dependence on foreign borrowing is reflected in commonly used indicators such as the ratio of outstanding debt to GDP and the ratio of debt servicing to export earnings. The debt-GDP ratio not only reflects the burden on a country's productive capacity, but also provides an insight into the sustainability of foreign debt in the long run. An increasing debt-GDP ratio implies that the growth rate of debt is higher than the growth rate of real GDP. This leads to a serious situation when the volume of foreign debt becomes unsustainable.

This increasing foreign dependency can be visualized by looking at the patterns of different debt indicators. Generally, these include the level of outstanding debt and debt servicing as ratios to GDP or foreign exchange reserves. The debt crisis in many developing countries emerged in the 1980s and peaked in the 1990s.

Figure 1 illustrates the position of selected Asian countries in terms of their outstanding external debt burden (debt-to-GDP ratio) from 1980 to 2010. In all cases, the external debt stock increases from 1980 to the 1990s, peaking in 1991. Thereafter, however, most countries return to roughly their 1980 position. This improvement may have been due to an increase in GDP rather than any considerable reduction in the stake of debt. 
Figure 1: Relative position of selected Asian countries: External debt-toGDP ratio

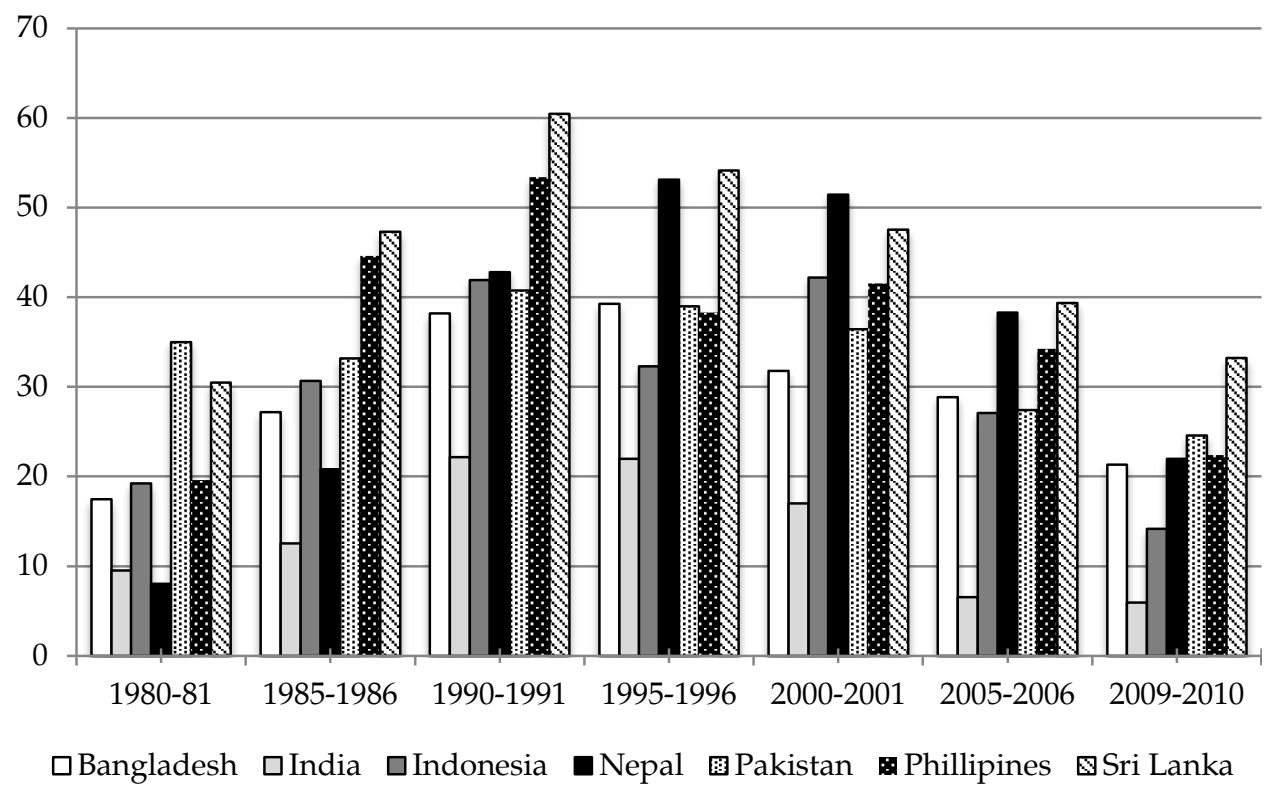

\subsection{Relationship Between Outstanding Debt and Social Sector Spending}

Public expenditure is an important determinant of economic growth and governments in developing countries have to spend appropriately in social sectors such as education and health. However, debt servicing can adversely affect constructive fiscal allocations in low-income countries. The very objective underlying foreign borrowing (to promote development) is depressed by servicing liabilities, which consumes a sizeable part of the scarce resources generated through exports and/or foreign remittances, and little is left behind to finance development.

However, since investment in the social sector is not directly productive, allocations for education and healthcare provision remain largely neglected in the budgeting process and fiscal considerations. This decelerates human capital development, with an indirect adverse impact on growth and the productivity of new investment in physical capital. Debt servicing shifts resources away from the social sector, especially health and education (Fosu, 2008). This is mainly because it is difficult for the government to cut down on other nondevelopment or recurring expenses. ${ }^{3}$

\footnotetext{
${ }^{3}$ The Appendix illustrates the relationship between debt servicing and public spending.
} 
Although the International Monetary Fund (IMF) proposed (or imposed) structural adjustment programs to reduce the volume of debt liability and ensure debt repayment, these have not worked well in developing Asian countries. In many cases, such programs have affected social welfare spending, as predicted by World Bank and IMF reports. Higher taxation and downsizing have led to rising unemployment and income reductions, while the removal of subsidies has caused the market prices of food items to increase, with grave implications for poor households. Thus, rather than alleviate poverty in the countries implementing these programs, they have merely aggravated the economic crisis.

For most developing countries, debt accumulation is seen as the root cause of their financial problems, including widening fiscal deficits. At a meeting of the OECD Development Assistance Committee in 1996, a number of socioeconomic targets were set for borrowing countries to be achieved by 2015 , that is, the OECD's assistance to developing countries was tied to visible progress in achieving these goals. Subsequently, the UN General Assembly approved the agenda of the Millennium Development Goals (MDGs) in 2003, which aimed at eradicating poverty and hunger, and providing better health and basic education, accompanied by a sustainable environment. However, most developing countries remain trapped in a vicious debt circle and, therefore, the focus is likely to be diverted from "welfare" to merely "survival." This makes achieving the MDGs a matter of chance in such countries, including Pakistan.

The persistence of heavy outstanding debt is, among other factors, detrimental to economic growth. The reduction in the pace of growth, in turn, implies lower household incomes and poor public revenue collection. Consequently, poverty is likely to rise, with an adverse impact on the social sectors. The dilemma for most developing countries, especially in Asia, is that the rise in nondevelopment expenditure has outstripped spending on the social sectors-to the extent that many governments are divesting themselves of the burden of providing basic health and education, and gradually shifting this to the private sector.

\subsection{Objectives and Rationale of the Study}

Keeping in view the above, the adverse impact of debt servicing on social sector spending (education and health) in developing countries 
is easily understood. ${ }^{4}$ Economic theory suggests that any increase in social sector spending will enhance social welfare by generating better employment opportunities in the long run, thereby increasing household income and access to food, education, and healthcare, and reducing the risk of economic adversity. There is a large body of literature on the determinants of government spending and the connection between government revenues and expenditures in developing countries (see, for instance, Snyder \& Yackovlev, 2000; Aisha \& Khatoon, 2009; Muritala \& Abayomi, 2011; Tayeh \& Mustafa, 2011).

Few studies, however, have assessed the impact of external debt on fiscal allocations in developing countries. In particular, the nexus between external debt burden and social sector spending needs further exploration. The present study attempts to fill this gap in the literature with reference to developing Asian countries. For this purpose, we have selected a panel of seven countries: Indonesia, the Philippines, Bangladesh, Nepal, India, Pakistan, and Sri Lanka for a 30-year period (1980-2010). These countries are moderately indebted and in somewhat similar stages of economic development. The study aims to determine how and to what extent the social sector is affected by external debt liability in these countries.

The next section briefly reviews the literature. Section 3 describes the model, methodology, and data; the results of the estimation are given in Section 4. Section 5 provides conclusions and policy implications.

\section{Literature Review}

The impact of external debt on social sector spending is a controversial issue. On the one hand, external borrowing boosts development spending (as is commonly perceived). On the other, debt repayment and servicing affects the government's ability to finance development programs (including social sector spending). The rationale for resorting to external borrowing is, therefore, obvious: developing countries need finances to boost economic growth and ensure smooth progress in all areas, including the social sector. However, the results of this experience of more than half a century have been different for different countries. Generally, public expenditures have increased on

${ }^{4}$ Of course, there are other factors responsible for this odd scenario besides debt liabilities. For instance, one reason may be the perception that providing education and healthcare is not solely the government's responsibility and that the private sector should come forward and contribute to that end. However, this expectation is only partially fulfilled in developing countries. While better-off households now rely on privately managed educational and health institutions, the majority of poor households have no option but to depend on the public sector. 
account of debt servicing. In contrast, government revenues have not kept pace, and thus the financing of debt servicing has resulted in public spending cuts in the social sector, especially in education and health.

Most researchers have focused on the determinants of public debt and its relationship with public revenues and expenditures. Many studies emphasize the implications of external capital inflows as well as the role of foreign aid in development programs. However, the literature generally bypasses the impact of the resulting debt stock on such programs or else yields mixed findings. A brief review is given below.

\subsection{External Debt Liability and General Public Spending}

Njeru (2003) investigates the growing external debt of Kenya and asks whether foreign aid has served as a substitute for domestic resources. Based on time-series data for 1970-1999, he concludes that foreign assistance increased government expenditures and boosted development spending.

McGillivray and Ouattara (2005) develop a link between debt servicing, aid, and fiscal variables for Côte d'Ivoire for the period 197599. Using the fiscal response model, they conclude that the bulk of the foreign aid offered to highly indebted poor countries (HIPCs) to meet their public spending needs, especially in the social sector, is misused. A large portion of this aid is used for debt servicing, which then has a negative impact on public spending. Another important result indicates that foreign aid does not induce a decline in borrowing-this finding contradicts the previous argument that public debt and foreign aid are substitutes for one another.

Hyman (2007) tests the contention that a heavy debt burden has had a negative impact on growth and development for the Caribbean states. He finds that external debt grew faster in these countries during the 1990s due to defaults on foreign debt and the jump in oil prices. Analyzing IMF data on the debt-GDP ratio for 1997-2006, the study concludes that governments are bound to reduce spending on basic social services (education and health) and infrastructure development when confronted by heavy debt servicing.

Raju (2008) uses an error correction model to investigate the relationship between government expenditure and revenues in India, using annual data for the period 1950-2003. The gap between expenditure and revenues increases the rate of interest, which in turn raises the cost of 
debt servicing and leads to further fiscal imbalances. Although the results are mixed, the study reveals a significant unidirectional causality running from increased revenues to enhanced development expenditures, with a positive impact on management.

Presbitero (2012) uses panel data for 92 low- and middle-income countries for the period 1990-2007. The study finds that public debt has a negative impact on growth up to a threshold of 90 percent of GDP, beyond which its effect becomes irrelevant. This nonlinear effect can be explained by country-specific factors since debt overhang is a constraint to growth in countries with sound macroeconomic policies and stable institutions.

In contrast to the studies above, $\mathrm{Wu}$, Tang, and Lin (2010) attempt to reassess the link between overall government expenditure and development spending by applying Granger causality tests to a panel of 182 countries (categorized by income level) over 1950 to 2004. The study concludes that high-income countries follow Wagner's law and the hypothesis that government spending helps raise public welfare and economic development. However, this is not true for low-income countries where government spending has little impact on economic development as a result of corruption and underdeveloped institutions.

\subsection{External Debt Liability and Social Sector Spending}

Stephens (2001) argues that debt servicing crowds out public sector "investment spending." Using panel data for 24 African HIPCs, the study finds that the increase in debt servicing has adversely affected expenditure on both education and health, but with a larger impact on the latter.

Baqir (2002) determines the impact of political and institutional factors on social sector spending in developing countries. He uses the "freedom index" as a proxy for the level of democracy and political structure, which is an important interpreter of government spending. Applying an ordinary least squares (OLS) model to panel data for more than 100 countries for the period 1985-98, he finds a strong relationship between democratization and government spending, particularly social expenditures, which implies that the social sector receives more attention in democratic countries.

Fan and Rao (2003) analyze public spending in 44 developing countries across Asia, Africa, and Latin America during 1980-2002. Applying the generalized method of moments (GMM) instrumental variable technique, they conclude that various types of government 
spending have a diverse impact on economic growth and development. The study suggests that governments should reduce their spending on defense and unproductive sectors, and focus on productive investment to reduce poverty and boost economic growth and development.

The argument that high debt servicing crowds out government social spending is analyzed by Loko, Mlachila, Nallari, and Kalonji (2003) through the relationship between external debt and poverty. Looking at 67 low-income countries over the period 1985-97, they report that governments most often reduce their spending on the social sectors (health, education, safety nets, and sanitation, etc.) because this is easier for them than making cuts in other sectors.

Mahdavi (2004) analyzes the impact of debt liability on different categories of public expenditure. Based on a sample of 47 developing countries for the period 1972-2001 and employing a random effects model, the study finds empirical evidence to support the view that external debt adversely affects both capital as well as current expenditure if wages and salaries are excluded. However, if wages and salaries are included, then the social sector seems to be protected (not affected by external debt liabilities) since these constitute a large part of social spending.

Ouattara (2006) suggests that external debt can adversely affect government spending in general. However, the social sector is more or less protected. In general, expenditure in capital-intensive sectors is reduced more than proportionately compared to current expenditure. Among the various headings of public expenditure, the infrastructure and productive sectors bear a larger burden in terms of debt servicing adjustments, while the defense and social sectors are relatively protected.

Lora and Olivera (2007) ask whether an increase in public debt (external and internal) affects social expenditures, if this effect depends on the reaction of other variables, and whether public debt affects health and education expenditures in the same way. Using a sample of 50 Latin American countries for the period 1985-2003, the results indicate that a higher debt stock is liable to cut down overall public expenditure and reduce social spending. Both education and health expenditures are adversely affected when the debt increases, but defaulting on it increases the spending on average.

Fosu $(2007,2008)$ applies a seemingly unrelated regression model to a panel of 35 African countries for the period 1975-94 and concludes that the debt constraint has a negative impact on education and health 
expenditures. However, he does not consider allocations to other functional sectors in this study. To fill this gap, he extends the analysis to a multi-sector model and estimates a system of expenditure-share equations simultaneously involving the functional sectors (agriculture, capital, economic services, public investment, education, and health). The study finds that the debt-servicing constraint is liable to shift public expenditure away from the social sectors (health and education) and possibly from public investment.

Fosu (2010) extends this analysis for sub-Saharan Africa, using a reduced-form simultaneous equations model. The study finds that debt servicing has a negative impact on social sector spending, particularly on education.

\subsection{Studies on Pakistan}

Pakistan has faced fiscal and trade deficit problems from the beginning and relied on domestic and foreign borrowing to fill the gaps. In developing countries, economic development depends largely on public sector spending since the private sector most often follows government initiatives. Although governments in such countries may want to allocate more to the social sectors, the outflows due to heavy debt servicing depress their productive fiscal spending capacity. There is very little work on the link between external debt liability and economic development in Pakistan, but the relevant studies are reviewed below.

Chaudhry, Malik, and Ramzan (2009) find evidence that foreign debt servicing has had a discouraging impact on constructive investment in Pakistan; this, in turn, has slowed down the pace of economic development. Using annual data for 1973-2006, the study concludes that foreign borrowing has had a negative influence on investment: foreign funds are not efficiently allocated due to poor governance, thereby affecting economic development. The authors suggest that the government should focus on proper planning and efficient implementation before inviting in foreign capital.

Ayyoub, Chaudhry, and Yaqub (2012) analyze the impact of external debt policy on the country's developing economy, using data for the period 1989/90 to 2009/10. The results put Pakistan in a bleak position: foreign money contributes the least to productivity, employment, and growth and development. That is, external debt liabilities have a negative impact on the pace of development. 
Summing up, external debt servicing clearly has an adverse impact on overall government spending and social sector spending in particular. Another key conclusion is that the outstanding debt burden per se has only a minimal effect on social spending: it is the debt servicing liability that shifts public spending away from education and health.

\section{Theoretical Background}

Low-income developing countries thus face an expenditureresource gap, with an investment-saving deficit and public sector budget deficit internally and a balance-of-trade deficit externally. Further, responsibility for accelerating the pace of development falls largely on the public sector, given that the private sector often lags behind and responds only to incentives from the government. As such, the latter has to rely on domestic and external borrowing, although it may of course receive some aid, grants, or assistance from donors on humanitarian grounds.

Foreign capital is beneficial in the short run if used carefully for growth and development and for institution building. It allows the government to finance its resource gaps and carry out development plans without affecting domestic investment. These projects, once complete, are expected to generate enough income to repay the country's debt and servicing liabilities.

However, if external resources are used to finance consumption expenditure (including military expenditures) or social sector projects that are (indirectly) productive only in the long run, or if such funds are misappropriated (via corruption or inefficient planning), then the stock of foreign debt becomes a deadweight. This is true of most HIPCs, where the practice of continuous borrowing translates over time into large stakes of outstanding debt and debt-servicing problems.

\subsection{The Model}

The analysis below is carried out in the form of three equations that are solved simultaneously.

\subsubsection{Overall Government Spending}

General expenditure (the annual budget) is determined by the availability of resources such as tax and nontax revenues, domestic borrowing, and foreign assistance. However, it also depends on foreign liabilities in terms of debt servicing, which in turn depends on the stock 
of external debt. A number of other social factors and government preferences also come into play. Thus:

$$
\text { GEXP = f (GREV, PPED, DSER, FAID, SPOL) }
$$

where

- GEXP = overall government spending (net of debt servicing) as a percentage of GDP

- $\mathrm{GREV}=$ government revenues as a percentage of GDP

- PPED = public and publicly guaranteed external debt stock as a percentage of GDP

- DSER = debt servicing (external liability) as a percentage of GDP

- $\quad$ FAID = foreign aid and transfer receipts as a percentage of GDP

- $\mathrm{SPOL}=$ other sociopolitical factors that might affect government spending.

All these variables are purely "economic," barring SPOL, which is noneconomic and qualitative. We use the freedom index data provided by Freedom House as a proxy for the sociopolitical conditions of the countries concerned (see Section 4). The relationship between the explanatory variables and the dependent variable (GEXP) may be positive (as in the case of GREV and FAID) or negative (as in the case of PPED and DSER). SPOL may have a positive impact on government spending if political conditions are normal and conducive, and a negative impact otherwise.

The above function can be written in linear form as

$$
\begin{array}{r}
G_{E X P_{i t}}=\alpha_{0}+\alpha_{1} G R E V_{i t}+\alpha_{2} P P E D_{i t}+\alpha_{3} D S E R_{i t}+\alpha_{4} F A I D_{i t}+ \\
\alpha_{5} S P O L_{i t}+e_{i t}
\end{array}
$$

The subscript $i$ stands for the $i$ th country and $t$ for the time (year). The error term $e$ is expected to be normally and independently distributed with a zero mean and constant variance.

\subsubsection{Development Expenditure}

Development expenditure or the volume of the capital budget is assumed to depend positively on the size of the overall budget (GEXP), the availability of foreign financial assistance (FAID), and the country's stage of 
economic development (represented by per capita GDP). The size of the budget deficit (DFCT) and the density of debt servicing (DSER) have to affect the development budget negatively. In addition, several other sociopolitical factors also affect the level of development expenditure. Thus:

$$
\mathrm{DEXP}=\mathrm{g}(\mathrm{GEXP}, \mathrm{GDPP}, \mathrm{DFCT}, \mathrm{FAID}, \mathrm{DSER})
$$

where DEXP is development expenditure as a percentage of GDP, GDPP is per capita GDP, and DFCT is the overall budget deficit as a percentage of GDP.

Again, the function can be expressed in linear form as

$$
\begin{array}{r}
D E X P_{i t}=\beta_{0}+\beta_{1} G E X P_{i t}+\beta_{2} G D P P_{i t}+\beta_{3} D F C T_{i t}+\beta_{4} F A I D_{i t}+ \\
\beta_{5} D S E R_{i t}+e_{i t}
\end{array}
$$

\subsubsection{Social Sector Spending}

The volume of public spending in the social sector depends positively on the total budget, particularly on allocations for development (DEXP), the level of education (LIT), the level of health (LEP), and other sociopolitical factors (SPOL). DSER is most likely to affect allocations for social spending negatively. Specifically, its impact may be more severe on the social sector than on government spending in other sectors. To analyze this phenomenon, we construct the following equation:

$$
\text { SEXP = h (DEXP, DSER, LIT, LEP, SPOL) }
$$

SEXP is the share of the social sector in total government spending, LIT is the literacy rate as a proxy for education, and LEP is life expectancy at birth as a proxy for health.

The linear version of this function is:

$$
\begin{array}{r}
S E X P_{i t}=\delta_{0}+\delta_{1} D E X P_{i t}+\delta_{2} D S E R_{i t}+\delta_{3} L I T_{i t}+\delta_{4} L E P_{i t}+ \\
\delta_{5} S P O L_{i t}+e_{i t}
\end{array}
$$

\subsection{Methodology}

The different methodologies used to evaluate the impact of external debt burden and servicing on public expenditure, particularly social spending, include OLS, fixed and random effects, and indirect least

squares. However, in this context, all these models are likely to face the 
problem of endogeneity bias since total government expenditure and its different components are obviously correlated. The explanatory variables, such as debt servicing and the overall budget deficit, are also components of the total budget. As such, this makes OLS an inappropriate technique. The proposed structural model would face an identification problem while indirect least squares is also unsuitable.

The literature suggests alternatives such as the full information maximum likelihood method, three-stage least squares, and GMM. We have opted for the latter, keeping in view the strengths and limitations of the methodologies used in different studies. GMM is commonly used to estimate simultaneous equation models: it combines a first-difference equation and a level equation involving lags as instruments to deal with the problem of endogeneity and to obtain additional efficiency gains from exploiting extra moment restrictions. This provides an opportunity to evaluate the lagged impact of outstanding debt as discussed by Fan and Rao (2003).

\subsection{Data Considerations}

The data for the main explanatory variables-the stock of external debt (public and publicly guaranteed), debt servicing, overall government expenditure, development, social expenditure, government revenues, and foreign aid-are taken from the World Development Indicators database, and expressed as ratios to GDP.

As discussed above, the model includes social and political conditions (SPOL) as an important determinant of public expenditure. Although it is a qualitative variable, the freedom index serves as a useful proxy. Compiled by Freedom House (a US-based organization) on the basis of a worldwide annual survey, the index gauges countries' level of democratization and political stability. ${ }^{5}$

\footnotetext{
${ }^{5}$ See www.freedomhouse.org. The variables included in the survey are civil liberties, political rights, and individual freedoms. Political rights gauge citizens' free participation in the political process. Civil liberties measure individuals' rights to express their ideas, institutional rights, and personal sovereignty without the influence of the state. Political freedom is bifurcated into a civil liberties index and a political rights index, both measured on a scale of 1 to 7 . The degree of political rights and civil liberties is reduced when the indices move up. The survey gives an opportunity to perform impulsively without interference from the government. It rates countries as free, partly free, or not free, depending on the scores assigned. Keeping in view these considerations, we have assigned a dummy of 1 if a country is rated "free" or "partly free" and 0 if it is rated "not free" in a certain year.
} 


\section{Model Estimation}

We start by estimating the first equation, which appears to be free of endogeneity, by applying OLS. The results, given in Table 1, are somewhat comparable with those obtained using GMM. ${ }^{6}$ Keeping in view the discussion above, we then apply GMM to the panel dataset for the seven countries. In this case, all three parts of the model are dealt with simultaneously, but the results for each are presented separately.

Table 1: OLS regression results for overall government expenditure

\begin{tabular}{lcccc} 
& \multicolumn{3}{c}{ Dependent variable $=$ government spending (ratio to GDP) } \\
\hline Variable & Coefficient & SE & t-statistic & Probability \\
\hline CONS & 1.26097 & 0.99681 & 1.26500 & 0.2075 \\
GREV & $1.26824^{* *}$ & 0.05263 & 24.09514 & 0.0000 \\
PPED & -0.00874 & 0.02328 & -0.37548 & 0.7077 \\
DSER & $-0.75667^{* *}$ & 0.15696 & -4.82065 & 0.0000 \\
FAID & $0.21962^{* *}$ & 0.08911 & 2.46473 & 0.0146 \\
SPOL & 0.74275 & 0.54513 & 1.36250 & 0.1747 \\
\hline \multicolumn{5}{c}{} \\
\hline R-squared (adj.) & & 0.740647 & \\
SE of regression & & 2.502974 & \\
Sum of squared residuals & 133.943000 & \\
Log likelihood & & -487.320800 & \\
F-statistic & & 18.624000 & \\
Prob. (F-statistic) & & 0.000000 & \\
Mean dependent variable & 18.727800 & \\
SD dependent variable & 4.914850 & \\
Akaike information criterion & & 4.823233 & \\
Schwarz criterion & 5.383954 & \\
Hannan-Quinn criterion & 5.049741 & \\
Durbin-Watson stat. & & 0.368893 & \\
\hline
\end{tabular}

Notes: Sample $=1980-2010$. Periods included $=31$. Cross-sections included $=7$. Total number of panel observations $=217$.

$*, * *$, and ${ }^{* * *}$ indicate significance at $1 \%, 5 \%$, and $10 \%$, respectively.

Source: Authors' calculations.

The robustness of the GMM results depend critically on the validity of the instruments used in the estimation. Hansen's J-statistic is

\footnotetext{
${ }^{6}$ However, the results of the remaining two sub-models are not reported, being inappropriate.
} 
widely applied for this purpose. The underlying null hypothesis in this case is that the instruments are uncorrelated with the residuals and are thus valid. The p-value associated with the J-statistic is 0.168977 , which clearly indicates that the null hypothesis cannot be rejected. In other words, the instruments used are orthogonal to the residuals, implying that the estimation results presented in the following tables are robust.

\subsection{Sub-Model 1: Overall Government Spending}

The regression results for overall government expenditure based on equation (1.1) are given in Table 2. Overall public expenditure (net of debt servicing) is postulated to depend on total tax and nontax revenues, the availability of foreign assistance, the prevailing sociopolitical conditions, and the debt-servicing liability. Apart from SPOL, all the other variables are expressed as ratios to GDP.

\subsubsection{Government Revenue (GREV)}

As expected, government revenue has a positive impact on government expenditure (public consumption + investment) and the coefficient is significant at the 5 percent level. Government spending increases in response to a rise in revenues for most of the sample countries such that an increase of 1 percent in government revenue leads government spending to rise by 1.31 percent. This result is intuitive and consistent with theory as well as with the findings of Raju (2008).

\subsubsection{Public and Publicly Guaranteed External Debt (PPED)}

Public and publicly guaranteed external debt has a negative impact on government spending, indicating that the outstanding debt burden reduces overall government spending. Although the coefficient is significant at 5 percent, the variable's impact is relatively small: an increase of 1 percent in the stock of external public debt lowers overall government expenditure by merely 0.016 percent. This is intuitive: the stock of outstanding debt is less important than its cost (debt servicing), provided that the debt is sustainable. In other words, it is at the stage of repayment that the stock of debt becomes a serious matter. 
Table 2: GMM regression results for overall government expenditure

\begin{tabular}{lcccc} 
& \multicolumn{3}{c}{ Dependent variable $=$ government spending (ratio to GDP) } \\
\hline Variable & Coefficient & SE & t-statistic & Probability \\
\hline CONS & 0.65670 & 0.91997 & 0.713830 & 0.4757 \\
GREV & $1.31472^{* *}$ & 0.06602 & 19.914540 & 0.0000 \\
PPED & $-0.01669^{* *}$ & 0.03652 & 0.457150 & 0.0648 \\
DSER & $-0.89552^{* *}$ & 0.27545 & -3.251140 & 0.0012 \\
FAID & $0.25641^{* *}$ & 0.10539 & 2.432760 & 0.0154 \\
SPOL & 1.27985 & 0.80277 & 1.594276 & 0.1116 \\
\hline \multicolumn{5}{c}{0.168977} \\
\hline J-statistic & & 0.734326 & \\
R-squared (adj.) & & 2.530305 & \\
SE of regression & & $1,171.647000$ & \\
Sum of squared residuals & & 18.799960 & \\
Mean dependent variable & & 4.909057 & \\
SD dependent variable & & 0.359206 & \\
Durbin-Watson stat. & &
\end{tabular}

Note: ${ }^{* * *}$, and ${ }^{* *}$ indicate significance at $1 \%, 5 \%$, and $10 \%$, respectively.

Source: Authors' calculations.

\subsubsection{Debt Servicing (DSER)}

Debt servicing (the payment of principal installments plus interest) is the most important variable in the model and has the expected negative sign with respect to government spending. The coefficient is significant at 5 percent, where an increase of 1 percent in debt servicing is likely to compel the government to cut its spending by 0.89 percent. The negative and significant relationship between debt servicing and government spending is supported by studies such as Baqir (2002) and Fosu (2010).

\subsubsection{Foreign Aid (FAID)}

Foreign aid has the expected positive relationship with overall government expenditure. This finding reflects the common wisdom: most of the sample's developing countries rely heavily on foreign assistance, particularly to support their development programs. The results show that an increase of 1 percent in foreign aid leads to a 0.25 percent increase in government spending, and the coefficient is significant at 5 percent. This is in line with Ouattara (2006) and Fosu (2010). 


\subsubsection{Sociopolitical Conditions (SPOL)}

As mentioned earlier, we would expect overall government expenditure to be higher in relatively democratic developing countries compared to those with authoritarian systems. Although the results indicate a positive relationship between better sociopolitical conditions and government spending as expected, the coefficient is not significant. This implies that the role of democracy and sociopolitical conditions is not as important to public expenditure in Asian countries as expected.

\subsection{Sub-Model 2: Development Spending}

Based on equation (2.1), Table 3 gives the regression results for development expenditure in the public sector within the system. This is postulated to depend on the level of the overall budget, GDP per capita, the availability of foreign assistance, and the debt-servicing liability. With the exception of per capita GDP, all the other variables are expressed as ratios to GDP.

Table 3: GMM regression results for development expenditure in public sector

Dependent variable $=$ development spending (ratio to GDP)

\begin{tabular}{lcccc}
\hline Variable & Coefficient & SE & t-statistic & Probability \\
\hline CONS & $8.12128^{* *}$ & 2.49706 & 35.29000 & 0.0000 \\
GEXP & $0.49286^{* *}$ & 0.22849 & -2.15698 & 0.0316 \\
GDPP & $0.03669^{* *}$ & 0.00552 & 6.64863 & 0.0000 \\
DFCT & -0.32796 & 0.43744 & -0.74972 & 0.4538 \\
FAID & $2.02406^{* *}$ & 0.20868 & 9.69920 & 0.0000 \\
DSER & $-4.12013^{* *}$ & 0.64712 & -6.36684 & 0.0000 \\
\hline \multicolumn{5}{r}{} \\
J-statistic & & & \\
R-squared (adj.) & & & 0.168977 \\
SE of regression & & & 0.187789 \\
Sum of squared residuals & & & 6.200459 \\
Mean dependent variable & & & 920.843000 \\
SD dependent variable & & & 6.850230 \\
Durbin-Watson stat. & & & 0.596091 \\
\hline
\end{tabular}

Note: ${ }^{*}{ }^{* *}$, and ${ }^{* * *}$ indicate significance at $1 \%, 5 \%$, and $10 \%$, respectively.

Source: Authors' calculations. 


\subsubsection{Overall Government Expenditure (GEXP)}

The results reveal a positive relationship between overall government spending and the portion allocated to development spending. This finding conforms to the theory that an increase in government expenditure should also enhance the fraction allocated to development spending. The relevant coefficient is significant at 5 percent and shows that a 1 percent increase in overall government expenditure will raise development spending by 0.49 percent. However, the situation is not encouraging: an increase in government spending may be absorbed more than proportionately by debt servicing and other nondevelopment factors, and the share of the development budget may be smaller.

\subsubsection{Per Capita GDP (GDPP)}

Per capita GDP, which reflects the level of economic development and growth, has the expected positive sign with respect to development expenditure. The coefficient is significant at 5 percent and indicates that an increase of 1 dollar in per capita GDP will increase development spending by 0.036 percent. This finding is in line with Fan and Rao (2003).

\subsubsection{Budget Deficit (DFCT)}

The overall budget deficit appears to have a negative effect on development spending. In theory, the budget deficit is likely to depress both development and nondevelopment expenditures, but the negative impact on the former is likely to be higher for developing countries, which ultimately reduces their productivity. Our results confirm this expectation. An increase in the budget deficit of 1 percent diminishes development spending by 0.32 percent, and the coefficient is significant at 5 percent. Mahdavi (2004) reports a similar finding.

\subsubsection{Foreign Economic Assistance (FAID)}

Foreign aid has the expected positive impact on development spending for the panel of countries. The coefficient is significant at 5 percent and shows that a 1 percent increase in foreign aid will raise development spending by 2.02 percent. This means that the availability of foreign assistance is the strongest motive for carrying forward and completing development projects in these countries. Whether the aid is utilized optimally is a different issue. Ouattara (2006) also indicates a positive relationship between foreign aid and development expenditure, although the coefficient is not significant in this case. 


\subsubsection{Debt Servicing (DSER)}

Debt servicing has the expected negative relationship with development spending. Intuitively, the greater the fraction of available resources taken up by debt servicing, the less there is to allocate to the development budget. Most previous studies support this finding. Our results indicate that a 1 percent increase in debt servicing pushes down development spending by 4.1 percent, at an acceptable significance level of 5 percent.

\subsection{Sub-Model 3: Social Sector Spending}

The regression results for social sector spending within the system as represented by equation (3.1) are given in Table 4. This variable should depend positively on the size of the development budget, the level of education denoted by the literacy rate (positive relationship), the level of health denoted by life expectancy at birth (positive relationship), the debt-servicing liability (negative relationship), and the level of sociopolitical development indicated by the freedom index (positive relationship). With the exception of life expectancy at birth, all other variables have the expected signs.

Table 4: GMM regression results for social expenditure in public sector

Dependent variable $=$ spending on education and health (ratios to GDP)

\begin{tabular}{lcccc}
\hline Variable & Coefficient & SE & t-statistic & Probability \\
\hline CONS & 1.77136 & 1.78786 & 0.99077 & 0.3224 \\
DEXP & $0.07340^{* *}$ & 0.02137 & 3.43497 & 0.0007 \\
DSER & $-0.25019^{* *}$ & 0.09092 & -2.75184 & 0.0062 \\
LIT & $0.06813^{* *}$ & 0.01148 & 5.93167 & 0.0000 \\
LEP & $-0.14187^{* *}$ & 0.03162 & -4.48631 & 0.0000 \\
SPOL & $0.58819^{* * *}$ & 0.29542 & 1.99101 & 0.0471 \\
\hline \multicolumn{5}{r}{} \\
J-statistic & & & \\
R-squared (adj.) & & & 0.168977 \\
SE of regression & & & 0.444518 \\
Sum of squared residuals & & & 0.808855 \\
Mean dependent variable & & & 3.770340 \\
SD dependent variable & & & 0.678753 \\
Durbin-Watson stat. & & & 0.361525 \\
Adj. R-squared & & & 0.734000 \\
\hline
\end{tabular}

Note: ${ }^{*}{ }^{* *}$, and ${ }^{* * *}$ indicate significance at $1 \%, 5 \%$, and $10 \%$, respectively.

Source: Authors' calculations. 


\subsubsection{Development Expenditure (DEXP)}

The allocation to development expenditure is a key determinant of social spending because any increase in development spending will push forward social sector spending (education and health in particular). The results confirm this positive relationship. The coefficient is significant at 5 percent and its value indicates that a 1 percent increase in the development budget will increase social spending by 0.073 percent for the panel of countries.

\subsubsection{Debt Servicing (DSER)}

The results confirm a negative relationship between the dependent (social sector spending) and explanatory variables (size of debt servicing). As the literature shows, an increase in debt servicing shifts resources away from the social sectors, especially education and health. The coefficient is significant at 5 percent and the results indicate that a 1 percent increase in debt servicing will decrease social sector spending by 0.25 percent. The results are consistent with Fosu (2010), who finds that debt servicing has a negative impact on social spending in sub-Saharan Africa.

\subsubsection{Literacy Rate (LIT)}

The results show that a 1 percent increase in literacy raises social spending by 0.068 percent. Dauda (2010) has also used the literacy rate as a proxy for education and found a similarly significant and positive relationship between social spending and literacy growth.

\subsubsection{Life Expectancy (LEP)}

The life expectancy proxy for health yields a result contrary to the theory and common wisdom. The coefficient is significant at 5 percent, but has a negative sign. This indicates that a 1 percent increase in life expectancy will reduce government spending in the social sector by 0.14 percent. Dimou and Chletsos (2011), who use a similar proxy for health, find that most developing countries in their sample incur high expenditures on healthcare, but have not developed their domestic pharmaceutical production. Thus, in order to finance healthcare imports, these countries have to rely on foreign borrowing. 


\subsubsection{Sociopolitical Conditions (SPOL)}

The results in this case indicate that sociopolitical development has a positive impact on social sector spending. The coefficient is significant at 10 percent and indicates that a 1 percent increase in sociopolitical stability will increase social spending by 0.58 percent. Thus, greater political stability and freedom of expression is associated with higher levels of social spending.

Based on the analysis above, the results obtained using GMM indicate that both the debt burden and debt servicing have a negative impact on overall government spending, development spending, and social spending (on education and health). A 1 percent increase in debt servicing is likely to compel the government to cut down its overall spending by 0.89 percent, its development spending by 4.1 percent, and its spending on the social sector by 0.25 percent. The results also suggest that GMM is best suited to analyzing the impact of debt servicing on public spending for panel data. All the results discussed above confirm the findings of previous studies carried out for other developing countries.

\section{Conclusion and Policy Implications}

The present study has attempted to explore the impact of external debt burdens on public spending in the social sector, particularly health and education. The model comprises a set of interlinked simultaneous equations (general government spending net of debt servicing, development spending, and social sector spending). The study uses data for 1980-2010 for a panel of seven developing Asian countries. The estimation is carried out within the GMM system framework. Besides other explanatory variables, each of the three equations includes debt servicing as an important determinant.

Our analysis confirms the general view in the literature that the debt-servicing liability has a negative impact on social sector spending, in this case, education and health. The higher the stock of external debt, the higher will be the debt-servicing liability. The case of external debt liability is, however, different from domestic public debt. External debt is serviced in terms of foreign exchange, which in turn has to be earned from exports or remittances. Further, the government has to cut down spending to release sufficient resources to this end. However, the (negative) distributional impact of this burden is heavy on the social sectors. Debt servicing reduces social sector spending in two ways: there 
is a direct negative impact (-0.25, Table 4), and further through an indirect effect that takes place via the impact on development expenditures ($4.1^{*} 0.73$, Table $3 \&$ Table 4 ).

In addition to debt servicing and other important determinants of public spending (revenues, the budget deficit, GDP per capita, and the availability of foreign aid), we have also included measures of democratization (in terms of freedom of expression as a dummy variable), health (in terms of life expectancy at birth), and education (in terms of the literacy rate) as determinants of social sector spending. The results indicate that greater democratic rights and higher levels of literacy lead to more social spending. In other words, democratic governments are more inclined toward social sector spending than authoritarian governments.

On this basis, some policy implications are discussed below.

Social sector development is a primary area of importance from an economic and political point of view. Our results indicate that it is negatively affected by external debt liability. In order to minimize this impact, policy managers should ensure that the burden of debt servicing is distributed evenly among different sectors of the economy. This can be done by significantly reducing unwarranted current (nondevelopment) expenditure, particularly on public administration. Defense expenditure could also be reduced to some extent, depending on countries' national security considerations.

The policy managers of indebted countries must negotiate with donor agencies to obtain lower rates of interest and to relax the rules regarding loan purpose, duration, negotiation fee, and moratorium commitments. Such measures would provide some degree of relief in debt obligations.

Dependence on domestic borrowing, particularly circular debt, should be minimized, given that the servicing liability consumes a considerable fraction of the scarce resources collected through taxation. ${ }^{7}$ Efforts should be made to enhance tax revenues to a level that is sufficient to finance current expenditure at the margin at least. This is essentially a function of efficiency in tax collection.

\footnotetext{
${ }^{7}$ Although the present study does not explicitly tackle this part of the debt issue, it is equally important and needs serious consideration.
} 
External loans must be purpose-specific and allocated efficiently to productive ends and development projects. In particular, misallocation of these resources should be curtailed and foreign direct investment strategies adopted to boost infrastructure development.

The role of sociopolitical factors in economic development, as shown by the impact of democratization on social spending, implies that developing countries must strengthen their democracies and demonstrate good governance.

Finally, developing countries should mobilize their own resources and gradually reduce dependence on foreign assistance. This will help conserve scarce resources (foreign exchange earnings from exports and remittances), which can then be channeled into development purposes, capital formation, and increased productivity in the long run, enabling these economies to move onto a path of sustainable growth. 


\section{References}

Aisha, Z., \& Khatoon, S. (2009). Government expenditure and tax revenue, causality and cointegration: The experience of Pakistan (1972-2007). Pakistan Development Review, 48(4), 951-959.

Ayyoub, M., Chaudhry, I. S., \& Yaqub, S. (2012). Debt burden of Pakistan: Impact and remedies for future. Universal Journal of Management and Social Sciences, 2(7), 29-40.

Baqir, R. (2002). Social sector spending in a panel of countries (Working Paper No. 02/35). Washington, DC: International Monetary Fund.

Chaudhry, I. S., Malik, S., \& Ramzan, M. (2009). Impact of foreign debt on savings and investment in Pakistan. Journal of Quality and Technology Management, 5(11), 101-115.

Clements, B. J., Bhattacharya, R., \& Nguyen, T. Q. (2003). External debt, public investment, and growth in low-income countries (Working Paper No. 03/249). Washington, DC: International Monetary Fund.

Dauda, R. O. S. (2010). Investment in education and economic growth in Nigeria: An empirical evidence. International Research Journal of Finance and Economics, 55, 158-169.

Dimou, S., \& Chletsos, M. (2011, July). Investigating the impact of healthcare spending on economic growth (28 OECD countries for 1990-2008). Paper presented at the $10^{\text {th }}$ Conference on Research on Economic Theory and Econometrics, Milos, Greece. Retrieved from (www.aueb.gr/conferences/Crete2011/PhD/Dimou.pdf).

Fan, S., \& Rao, N. (2003). Public spending in developing countries: Trends, determination, and impact (EPTD Discussion Paper No. 99). Washington, DC: International Food Policy Research Institute.

Fosu, A. K. (2007). Fiscal allocation for education in sub-Saharan Africa: Implications of the external debt service constraint. World Development, 35(4), 702-713.

Fosu, A. K. (2008). Implications of the external debt-servicing constraint for public health expenditure in sub-Saharan Africa. Oxford Development Studies, 36(4), 363-377. 
Fosu, A. K. (2010). The external debt-servicing constraint and public expenditure composition in sub-Saharan Africa. African Development Review, 22(3), 378-393.

Hyman, R. (2007, September). The impact of high debt burdens on small Caribbean states. Paper presented at the Conference on Economic Growth and Transformation ("Reassessing the Challenges at the Dawn of the $21^{\text {st }}$ Century"), Kingston, Jamaica.

Islamov, B. (2001). Central Asia: Problems of external debt and its sustainability (Discussion Paper Series A No. 413). Tokyo: Hitotsubashi University, Institute of Economic Research.

Loko, B., Mlachila, M., Nallari, R., \& Kalonji, K. (2003). The impact of external indebtedness on poverty in low-income countries (Working Paper No. 03/61). Washington, DC: International Monetary Fund.

Lora, E., \& Olivera, M. (2007). Public debt and social expenditure: Friends or foes? Emerging Markets Review, 8(4), 299-310.

Mahdavi, S. (2004). Shifts in the composition of government spending in response to external debt burden. World Development, 32(7), 11391157.

McGillivray, M., \& Ouattara, B. (2005). Aid, debt burden and government fiscal behavior in Côte d'Ivoire. Journal of African Economies, 14(2), 247-269.

Muritala, T. A., \& Abayomi, T. (2011). Government expenditure and economic development: Empirical evidence from Nigeria. European Journal of Business and Management, 3(9), 18-28.

Ngassam, C. (1991). Factors affecting the external debt-servicing capacity of African nations: An empirical investigation. Review of Black Political Economy, 20(2), 45-64.

Njeru, J. (2003). The impact of foreign aid on public expenditure: The case of Kenya (Research Paper No. 135). Nairobi: African Economic Research Consortium. Retrieved from (www.aercafrica.org/ documents/rp135.pdf). 
Ouattara, B. (2006). Foreign aid and government fiscal behavior in developing countries: Panel data evidence. Economic Modelling, 23(3), 506-514.

Presbitero, A. F. (2012). Total public debt and growth in developing countries. European Journal of Development Research, 24(4), 606-626.

Rais, S. I., \& Anwar, T. (2012). Public debt and economic growth in Pakistan: A time series analysis from 1972 to 2010. Academic Research International, 2(1), 535-544.

Raju, S. (2008). The revenue-expenditure nexus: Evidence for India. Contemporary Issues and Ideas in Social Sciences, 4(2), 1-33.

Shonchoy, A. (2010). What is happening with the government expenditure of developing countries: A panel data study. In Proceedings of the German Development Economics Conference, Hannover 2010 (No. 2). Frankfurt: German Economic Association.

Siddiqui, R., \& Malik, A. (2001). Debt and economic growth in South Asia. Pakistan Development Review, 40(4), 677-688.

Snyder, J. M., \& Yackovlev, I. (2000). Political and economic determinants of government spending on social protection programs. Unpublished manuscript, Massachusetts Institute of Technology, Cambridge. Retrieved from (http:/ / economics.mit.edu/files/1207).

Stephens, M. (2001). External debt, government spending and growth in heavily indebted poor countries. Unpublished PhD thesis, New York University, NY.

Tayeh, S. N. A., \& Mustafa, M. H. (2011). The determinants of public expenditures in Jordan. International Journal of Business and Social Science, 2(8), 45-49.

World Bank. (2010). World development indicators. Retrieved from (www.data.worldbank.org/sites/default/files/wdi-final.pdf).

Wu, S.-Y., Tang, J.-H., \& Lin, E. S. (2010). The impact of government expenditure on economic growth: How sensitive to the level of development? Journal of Policy Modelling, 32(6), 804-817. 


\section{Appendix}

\section{An Overview of Asian Developing Countries}

Most developing countries have to rely on external resources, generally in the form of interest-bearing loans, foreign aid on easy terms, and sometimes donations. Such countries are in the initial phase of development and, therefore, need greater financial support. It is generally argued that the flow of resources from resource-surplus to resourcedeficient countries enhances economic efficiency and welfare.

However, this is not true of developing countries facing large fiscal and trade deficits, many of which are hampered by lavish spending on nondevelopment projects, corruption and large governments. Likewise, they are bound to face a persistent deficit on the balance-of-payments current account. This practice not only increases the need for further borrowing, both internal and external, but also raises the proportion of current expenditure in the total budget due to debt servicing.

For many developing countries, the problem of debt accumulation started in 1973 with the tremendous increase in world petroleum prices. Developing non-OPEC countries were trapped in this price hike and their import bills for other manufactured goods also increased. Industrial countries found they could easily accommodate the oil price hike in exportable goods and shift the burden of inflation onto developing countries, which then had no option but to approach the IMF, World Bank, and other international agencies to meet their budgetary gaps and finance their imports. In many developing countries, the debt-GDP ratio is more than their GDP while debt servicing exceeds 25 percent of their export earnings.

Empirical analyses show that the ratio of debt to GDP and of debt servicing to GDP or export earnings can be meaningful in measuring the debt burden. If these ratios happen to be more than the critical values, ${ }^{8}$ then the impact of the debt burden is negative on government spending and economic development.

There is a large variation among developing Asian countries when we compare these ratios. For instance, during the 1990s, the overall debtto-GDP ratio was more than the critical value (> 50 percent) for Sri Lanka and Pakistan, but less for India (Global Development Finance, 2001). However, this trend has changed for some Asian countries over time. In

\footnotetext{
${ }^{8}$ According to the World Bank, the critical value of debt-to-GDP is 80 percent.
} 
some cases, the debt situation has become critical and had negative effects on the economy (Siddiqui \& Malik, 2001).

\section{Relationship Between Debt Servicing and Economic Indicators}

The debt-servicing-to-GDP ratio is an important indicator of debt sustainability because it shows how much of a country's GDP will be absorbed in servicing the debt burden. Economic theory suggests a negative relationship between debt servicing and development as well as social sector expenditure. We discuss this below in the context of the seven sample countries. All indicators are expressed as ratios to GDP.

\section{Bangladesh}

As Figure A1 shows, the external debt-servicing-to-GDP ratio for Bangladesh grew between 1980 and 1999, increasing from 0.42 percent in 1980 to 1.79 percent by the end of 1999 . Thereafter, it declined, standing at 0.98 percent in $2009 / 10$. This improved social sector spending from 1.6 percent in 1980 to 3.7 percent by the end of 2010 .

Figure A1: Debt servicing and expenditure (current, development, and social) in Bangladesh

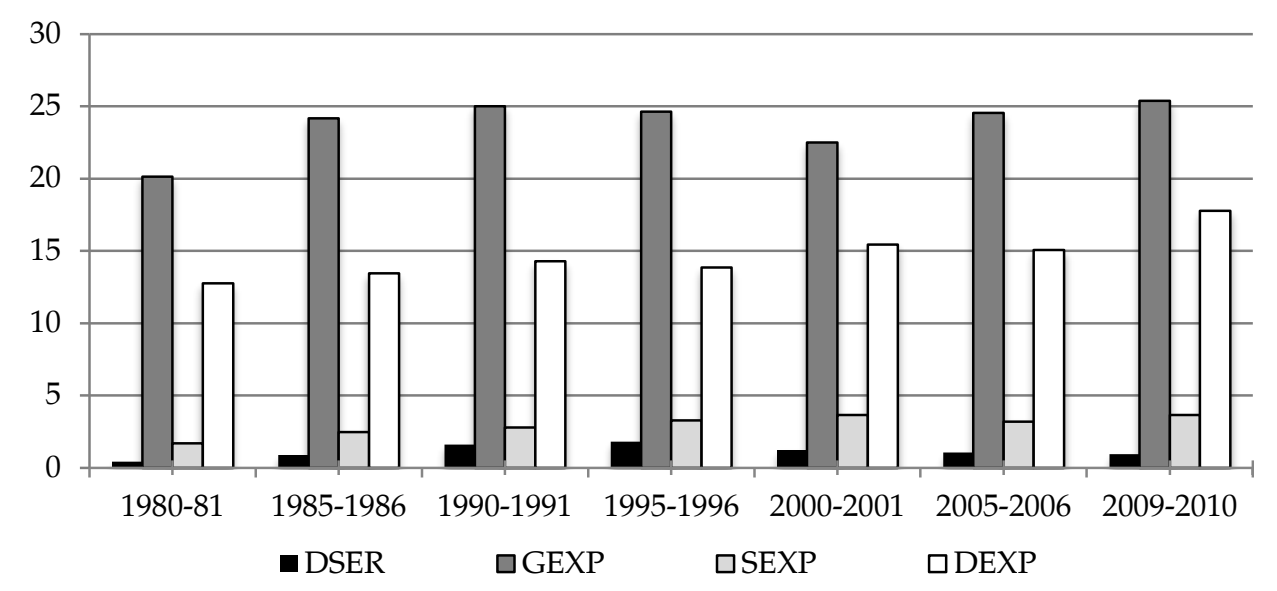

India

India is better off than other countries in South and Southeast Asia in terms of debt servicing. As the largest economy in the region, its debt servicing-GDP ratio looks to be very small, although the nominal value is not so low. Likewise, the country's pace of development and growth is relatively high. 
Figure A2 shows that development spending improved 1991 onward, but social sector spending continued to diminish during this period. This declining trend is difficult to explain. However, as the debtservicing ratio continued to increase from 0.61 percent in 1980 to 2.9 percent in 2003. Social sector spending roughly doubled in the span of 30 years, from 1.2 percent in 1980 to 4.5 percent of GDP in 2010.

Figure A2: Debt servicing and expenditure (current, development, and social) in India

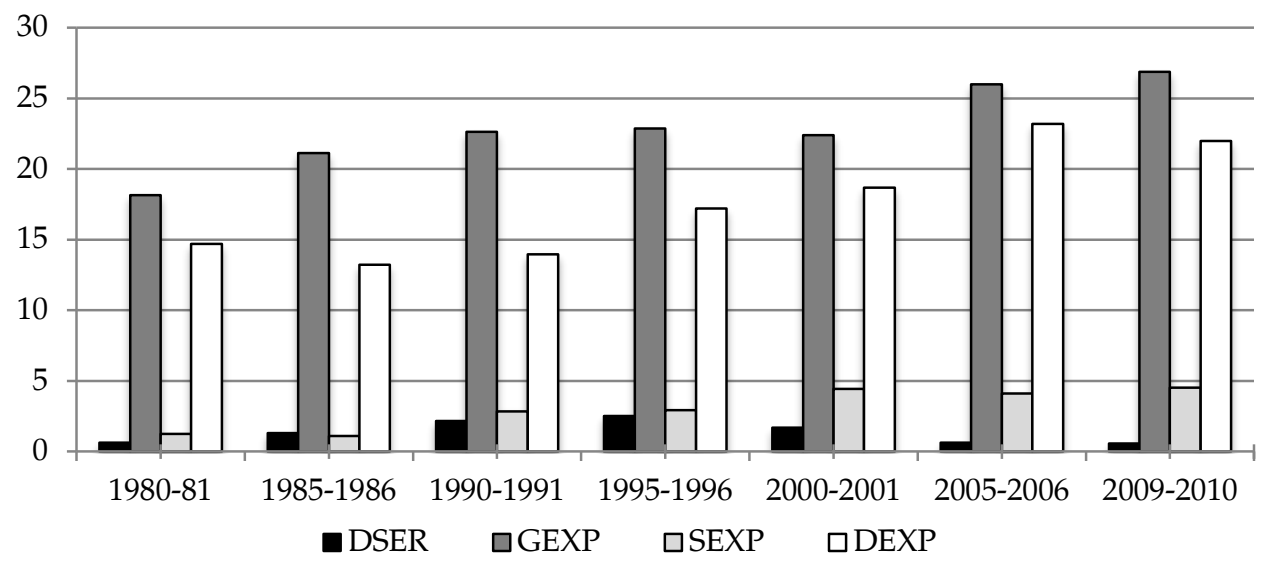

Pakistan

Pakistan has, unfortunately, suffered acutely from problems of terrorism and deteriorating law and order after 9/11, which has adversely affected its economic development and growth.

Figure A3 indicates that the debt servicing-GDP ratio continued to increase from 1980 to 1996, after which it declined, reaching 1.6 percent by the end of 2010. Social spending has an inverse relationship with debt servicing. It declined from 4.8 percent in 1980 to 2.2 percent in 1996, improved slightly in 1997, reaching 3.9 percent, but again falling to 2.8 percent in 2010. Although Pakistan received substantial funds from donor agencies in 2009/10, it could not mobilize these resources efficiently toward social sector and overall development due to poor governance and corruption. Public expenditure is extremely high in the current (nondevelopment) budget compared to social sector spending in health and education. 
Figure A3: Debt servicing and expenditure (current, development, and social) in Pakistan

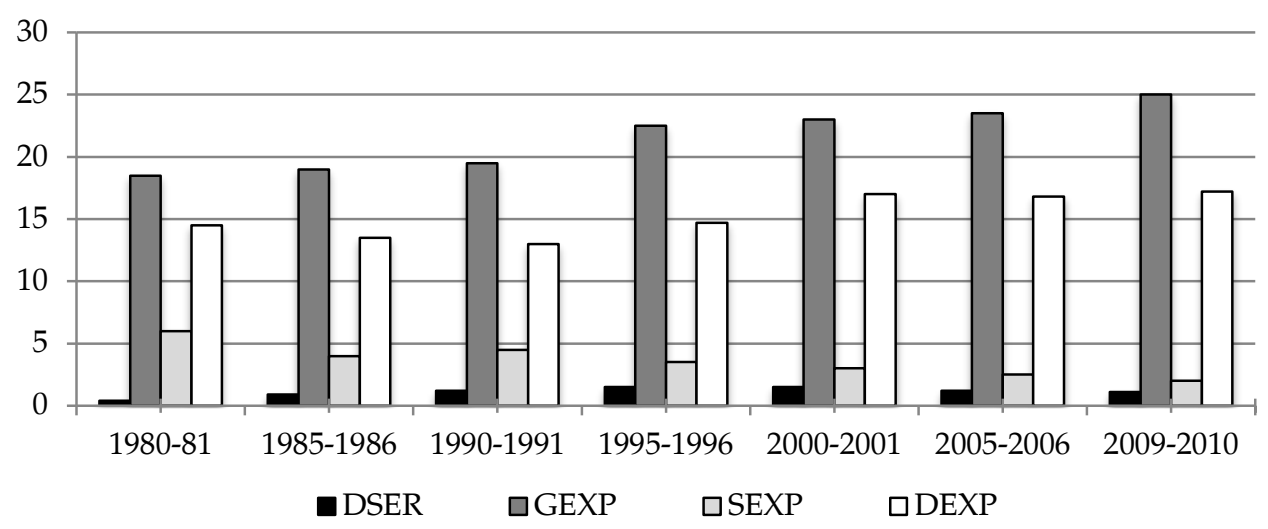

Nepal

Figure A4 illustrates debt servicing and current, development, and social expenditures in Nepal over the past 30 years. The debt servicingGDP ratio gradually increased from 0.25 percent of GDP in 1980 to 1.3 percent by the end of 2010; social sector spending in the public sector fell continuously from 5.6 percent in 1980 to 1.9 percent by the end of 2010 . This establishes the inverse relationship between debt servicing and social sector spending. Overall development spending, however, shows a declining trend from 1980 to 1990 and then a continuous increasing trend thereafter. Thus, the relationship between development spending and its component, social sector spending, is not clear in this case.

Figure A4: Debt servicing and expenditure (current, development, and social) in Nepal

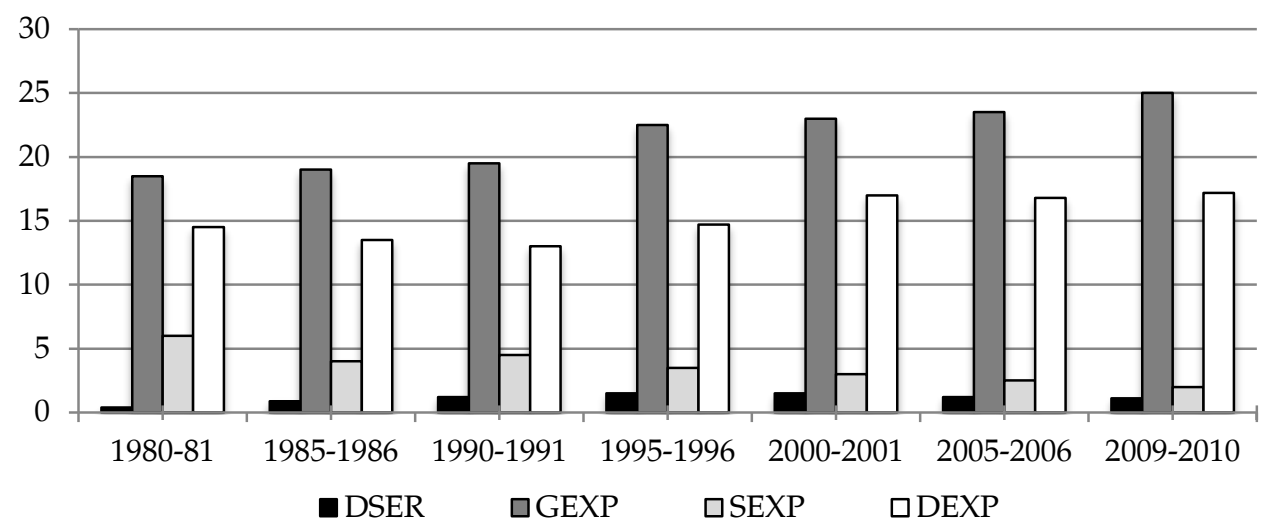




\section{Sri Lanka}

Sri Lanka remained in political turmoil during the 1980s and 1990s. Although its outstanding public external debt-to-GDP ratio is higher than that of the other countries under reference, as theory suggests, the stock of outstanding debt has had a minimal effect on social sector spending. In contrast, it is the cost of debt (servicing) that is important.

Figure A5 indicates that the debt servicing-GDP ratio followed an increasing trend from 1980 to 2001 (from 2.0 to 3.7 percent). However, it then declined to 2.3 percent by the end of 2010, indicating an improvement. Social sector spending, however, improved from 1.19 percent in 1980 to 4.7 percent in 2005. Declining somewhat in 2006, it then improved and stood at 3.9 percent of GDP at the end of 2010.

Figure A5: Debt servicing and expenditure (current, development, and social) in Sri Lanka

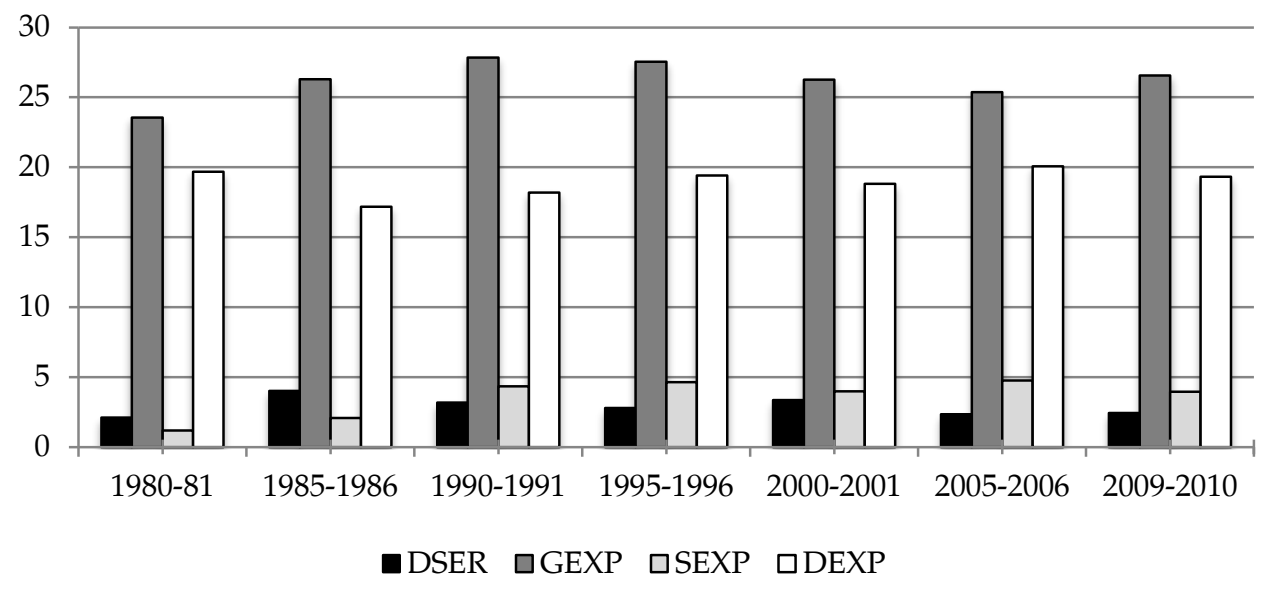

The Philippines

As Figure A6 shows, there is an almost inverse relationship between the debt servicing-GDP ratio and social sector spending in the Philippines over the 30-year period. The graph indicates fluctuations in debt servicing as well as current, development, and social spending. The debt servicing-GDP ratio continued to increase till 2001, i.e., from 1.8 percent in 1980 to 7.1 percent in 2001. Thereafter, the ratio gradually declined and stood at 4.9 percent of GDP at the end of 2010. Consequently, the social sector spending-GDP ratio also declined from 
3.6 percent in 1980 to 2.4 percent in 2001, after which it increased, standing at 3.0 percent of GDP by the end of 2010 .

Figure A6: Debt servicing and expenditure (current, development, and social) in the Philippines

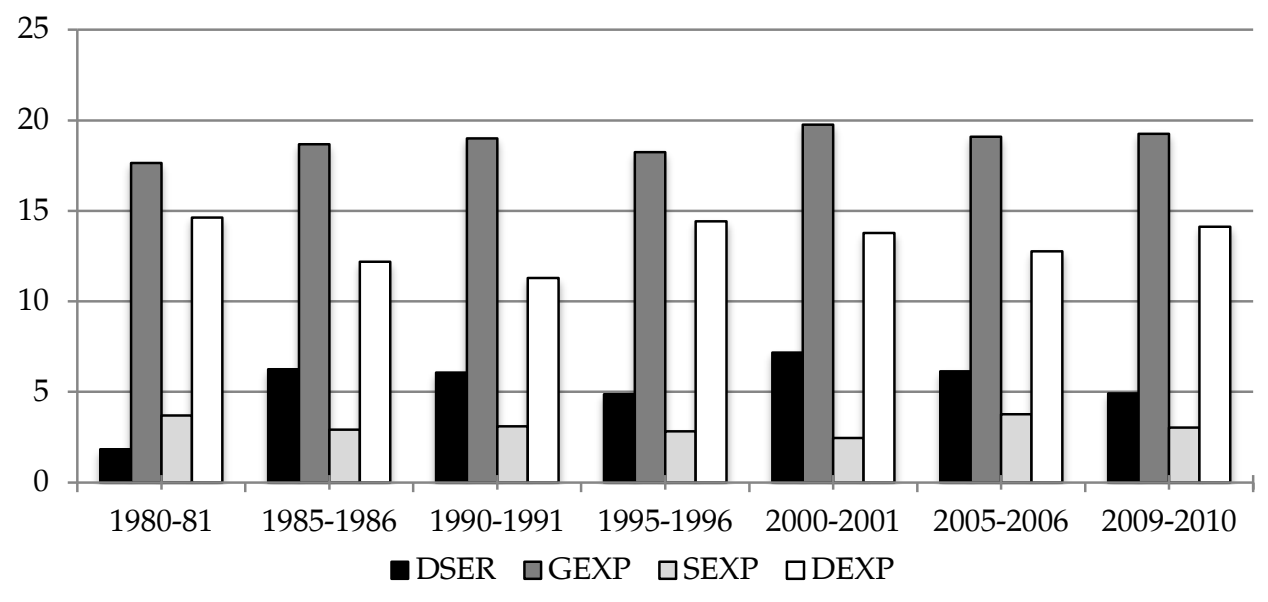

Indonesia

Figure A7 indicates that Indonesia's debt-servicing ratio rose from 2.2 percent of GDP in 1980 to 6.6 percent in 1999. After 2001, the debtservicing ratio started to decline and stood at 1.25 percent of GDP in 2010. This, in turn, improved social sector spending from 0.51 percent in 1980 to 4.2 percent in 2010 .

Figure A7: Debt servicing and expenditure (current, development, and social) in Indonesia

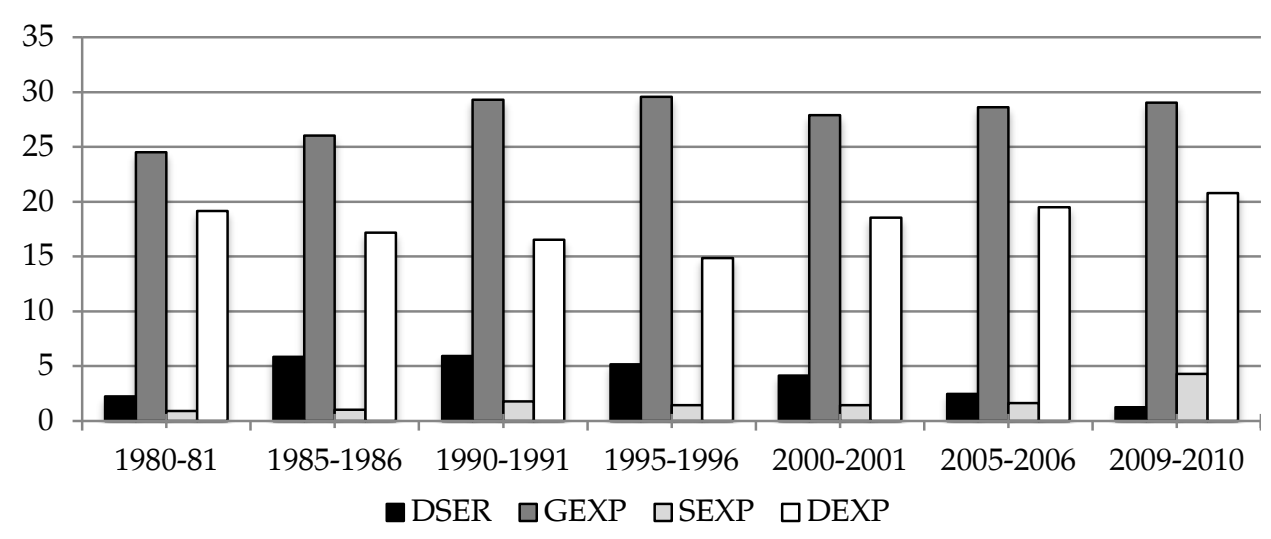

